\title{
Pelaksanaan Pendidikan Inklusif dalam kalangan Guru Arus Perdana
}

\section{(Implementation of Inclusive Education Among Mainstream Teachers)}

\author{
Noor Syahira Jalaluddin 1*iD, Mohd Mokhtar Tahar² (D) \\ 1Fakulti Pendidikan, Universiti Kebangsaan Malaysia (UKM), 43600, Bangi, Selangor, Malaysia. \\ Email: P102847@siswa.ukm.edu.my \\ ${ }^{2}$ Fakulti Pendidikan, Universiti Kebangsaan Malaysia (UKM), 43600, Bangi, Selangor, Malaysia. \\ Email: mokhtar@ukm.edu.my
}

\section{CORRESPONDING \\ AUTHOR (*): \\ Noor Syahira Jalaluddin \\ (P102847@siswa.ukm.edu.my)}

\section{KATA KUNCI:}

Pendidikan inklusif

Pedagogi inklusif

Guru arus perdana

Murid masalah pembelajaran

\section{KEYWORDS:}

Inclusive Education

Pedagogy Inclusive

Mainstream teachers

Students with learning

disabilities

\section{CITATION:}

Noor Syahira Jalaluddin \& Mohd Mokhtar Tahar. (2022). Pelaksanaan Pendidikan Inklusif dalam kalangan Guru Arus Perdana. Malaysian Journal of Social Sciences and Humanities (MJSSH), 7(2), e001280. https://doi.org/10.47405/mjssh.v7i2.1280

\section{ABSTRAK}

Kajian ini bertujuan untuk mengenal pasti pelaksanaan pendidikan inklusif dalam kalangan guru arus perdana yang dilaksanakan di dua buah sekolah rendah yang melaksanakan pendidikan inklusif di Melaka Tengah. Kaedah kualitatif berbentuk kajian kes menggunakan Teori Pelaziman Operan Thorndike dan Model Le Francois. Kajian ini melibatkan sampel seramai lima orang guru arus perdana yang melaksanakan pendidikan inklusif. Kesahan dan kebolehpercayaan dilakukan melalui kaedah triangulasi iaitu menggunakan lebih daripada satu kaedah untuk mengumpul data. Data dikumpulkan melalui temu bual dan pemerhatian. Semua dapatan data akan dianalisis menggunakan aplikasi Nvivo untuk mendapatkan maklumat tentang bagaimana pedagogi inklusif dilaksanakan oleh guru-guru yang dipilih dalam kajian ini. Hasil kajian ini mendapati pelaksanaan pendidikan inklusif adalah di tahap sederhana di mana guru-guru arus perdana yang melaksanakan pendidikan inklusif dapat dikategorikan sebagai guru yang mempunyai pengetahuan mengenai pendidikan inklusif dan mereka juga melaksanakan pedagogi inklusif di dalam kelas. Walau bagaimanapun, masih juga terdapat di antara peserta kajian yang dapat dilihat masih kurang pengetahuan mengenai perancangan proses pengajaran dan pembelajaran Program Pendidikan Inklusif. Kesimpulannya, semua pihak haruslah memainkan peranan serta menitik beratkan pelaksanaan pendidikan inklusif di sekolah supaya dapat menjayakan usaha kerajaan bagi memantapkan pelaksanaan pendidikan inklusif di negara kita.

\section{ABSTRACT}

The research was intended to identify the application of inclusive education program among mainstream teachers that was implemented by two primary schools located in Malacca. The qualitative methods adopted for assessing the 
case studies were Thorndike's Theory of Operant Conditioning and Le Francois Model. The research had sampled five mainstream teachers that had implemented the inclusive education. The validity and reliability of the research was completed through the triangulation technique that used more than one method of collecting sample data. The data was collected through observations and in-person interviews, and analysed using the Nvivo application to identify insights and information regarding the pedagogy inclusive implemented by the mainstream teachers. The research had identified that the implementation of inclusive education among the mainstream teachers were implemented modestly, and the mainstream teachers were found to be knowledgeable of the Inclusive Education Programme, and adopted the pedagogy inclusive in their classroom. However, the research also identified that there were some mainstream teachers lacked in understanding of the planning process required by the Inclusive Education Program. In conclusion, all parties are responsible to activately participate in educating, training, and raising awareness around the inclusive education to ensure the success of the program and strengthen the overall education system in Malaysia.

Sumbangan/Keaslian: Sumbangan utama kajian ini ialah mendapati bahawa masih terdapat guru arus perdana yang kurang pengetahuan mengenai perancangan proses pengajaran dan pembelajaran yang sepatutnya dilaksanakan semasa menjalankan pendidikan inklusif di dalam bilik darjah.

\section{Pengenalan}

Pendidikan merupakan salah satu bidang yang menyumbang kepada pembangunan sesebuah negara. Negara Malaysia telah memberi satu komitmen untuk melaksanakan Program Pendidikan Inklusif (PPI) iaitu salah satu usaha untuk memastikan semua murid mendapatkan pendidikan di negara kita termasuklah murid berkeperluan khas. Pendidikan inklusif telah dicipta khas untuk murid yang mempunyai keperluan pendidikan khas untuk belajar bersama-sama dengan murid arus perdana (Norfishah et al., 2018). Murid berkeperluan khas (MBK) dan murid arus perdana ditempatkan di dalam satu kelas yang sama dan suasana yang sama serta menggunakan Kurikulum Kebangsaan yang sama dan akan diajar oleh guru arus perdana (Lewis \& Doorlag, 2011). Di Malaysia, terdapat dua kategori pendidikan inklusif yang dilaksanakan di sekolahsekolah iaitu pendidikan inklusif secara separa dan secara penuh. Menurut Tin dan Wah (2018), inklusif secara separa ialah apabila murid berkeperluan khas hanya mengikuti beberapa mata pelajaran tertentu sahaja di dalam kelas arus perdana seperti mata pelajaran Bahasa Melayu, Matematik mahupun Pendidikan Jasmani. Manakala, bagi inklusif penuh, murid berkeperluan khas akan sepenuhnya mengikuti pengajaran dan pembelajaran (PdP) di kelas arus perdana. Caldwell (2010) mendapati bahawa faedah program inklusif penuh ialah murid dapat meningkatkan perkembangan dalam aspek sosial dan akademik kerana MBK berpeluang untuk mewujudkan komunikasi serta interaksi sosial yang berkesan dengan rakan sebaya mahupun orang yang berada di sekelilingnya. 
Pendidikan inklusif di Malaysia telah diperkenalkan hasil sumbangan pelbagai dasar yang secara tidak langsung telah menjadikan pendidikan khas semakin berkembang. Terdapat beberapa dasar yang berkaitan dengan pendidikan inklusif dan salah satunya adalah Penyataan Salamanca dan Rangka Kerja Tindakan terhadap pendidikan khas (UNESCO, 1994). Secara ringkasnya Penyataan Salamanca menegaskan bahawa kanakkanak dan remaja yang dikategorikan sebagai berkeperluan khas seharusnya dapat mengikuti sistem yang dibina untuk kebanyakan kanak-kanak (Florian, 2019). Justeru menurut Tin dan Wah (2018), setiap sekolah haruslah mengiktiraf dan memberikan respons kepada pelbagai keperluan khas yang diperlukan murid, gaya dan kadar pembelajaran yang berbeza, menggunakan kurikulum, strategi pengajaran dan penggunaan sumber yang bersesuaian serta dapat bekerjasama dengan komuniti bagi memastikan semua murid mendapat pendidikan yang berkualiti tanpa diskriminasi. Menurut Florian (2019), seruan Penyataan Salamanca juga telah berjaya mencetuskan banyak usaha untuk menyokong kanak-kanak berkeperluan khas untuk akses kepada sistem pendidikan arus perdana di banyak negara.

Justeru, dalam memastikan Program Pendidikan Inklusif dapat dilaksanakan dengan baik, semua pihak yang terlibat sama ada secara langsung mahupun tidak langsung haruslah mempunyai pengetahuan dan memahami akan kepentingan pendidikan inklusif terutamanya bagi guru yang terlibat dalam melaksanakan pendidikan inklusif. Hal ini haruslah diberikan perhatian yang serius supaya MBK dapat menerima pendidikan yang sesuai dan relevan seperti murid tipikal agar selaras dengan prinsip pendidikan untuk semua (Mohammad Azman, Roslee \& Muhamad Suhaimi, 2019). Terdapat beberapa masalah yang sering dilihat dalam melaksanakan pendidikan inklusif. Salah satunya adalah guru arus perdana kurang ilmu pengetahuan mengenai keperluan Murid Berkeperluan Khas (MBK). Salah satu kajian lepas berkaitan pendidikan inklusif ialah kajian yang telah dijalankan oleh Norliah dan Mohd Hanafi (2016). Hasil kajian mendapati, masih terdapat guru yang menggunakan teknik serta kaedah PdP yang sama bagi semua murid semasa melaksanakan PPI meskipun terdapat MBK di dalam kelas tersebut. Hal ini telah menyebabkan terdapat murid PPI yang ketinggalan dalam mengikuti pengajaran guru. Malah, murid PPI juga kerap tidak dapat menyiapkan tugasan mahupun latihan yang diberikan oleh guru.

Walau bagaimanapun, kebanyakan kajian yang dijalankan adalah berkaitan kesediaan guru melaksanakan Program Pendidikan Inklusif, tetapi kurang menyentuh mengenai cara guru melaksanakan PPI di dalam bilik darjah. Malah, kajian yang dijalankan juga kebanyakannya menggunakan kaedah kuantitatif. Hasil kajian ini diharapkan dapat memberikan satu gambaran umum mengenai tahap kemahiran pedagogi inklusif guru aliran perdana yang menjalankan Program Pendidikan Inklusif dari aspek strategi pengajaran. Justeru, tujuan kajian ini dijalankan adalah untuk mengenal pasti pengetahuan berkaitan pendidikan inklusif dalam kalangan guru arus perdana, serta mengenal pasti pelaksanaan proses pengajaran bagi sebelum, semasa dan selepas guru arus perdana melaksanakan pendidikan inklusif di dalam bilik darjah. Kajian ini juga akan menerangkan mengenai tinjauan literatur dan metodologi. Seterusnya akan diikuti dengan dapatan kajian, perbincangan, limitasi kajian dan cadangan kajian lanjutan.

\section{Tinjauan Literatur}

Salah satu kajian lepas berkaitan pendidikan inklusif ialah kajian yang telah dijalankan oleh Norliah dan Mohd Hanafi (2016). Kajian ini adalah bertujuan untuk menilai pelaksanaan PPI dalam Gelombang 1 Pelan Pembangunan Pendidikan Malaysia (PPPM) 
2013-2015 berikutan ketetapan dasar yang dibuat oleh Kementerian Pendidikan Malaysia (KPM) bagi menyasarkan 30\% penyertaan MBK dalam sistem pendidikan arus perdana. Hasil kajian mendapati, masih terdapat guru yang menggunakan teknik serta kaedah PdP yang sama bagi semua murid semasa melaksanakan PPI meskipun terdapat MBK di dalam kelas tersebut. Hal ini telah menyebabkan terdapat murid PPI yang ketinggalan dalam mengikuti pengajaran guru. Malah, murid PPI juga kerap tidak dapat menyiapkan tugasan mahupun latihan yang diberikan oleh guru. Walau bagaimanapun, pengkaji mendapati terdapat $40 \%$ guru berupaya mengajar dengan berkesan dan menyediakan laporan komprehensif berkaitan prestasi murid PPI.

Seterusnya, sikap positif yang terdapat dalam diri seseorang guru merupakan perkara penting bagi menentukan kejayaan pelaksanaan pendidikan inklusif di dalam bilik darjah semasa proses pengajaran dan pembelajaran dijalankan. Justeru, Saloviita (2020) telah menjalankan satu kajian kuantitatif berkaitan sikap guru terhadap pelaksanaan pendidikan inklusif. Kajian ini melibatkan jumlah responden yang besar iaitu seramai 1764 orang guru. Responden terdiri daripada 824 orang guru kelas, 575 orang guru mata pelajaran yang melaksanakan pendidikan inklusif dan 365 orang guru pendidikan khas. Hasil kajian mendapati, terdapat perbezaan antara sikap guru kelas, guru mata pelajaran yang melaksanakan pendidikan inklusif dan juga guru pendidikan khas iaitu guru pendidikan khas dikatakan mempunyai sikap yang lebih positif berbanding keduadua kategori yang lain. Justeru, perkara ini menunjukkan bahawa terdapat guru arus perdana yang melaksanakan pendidikan inklusif mempunyai sikap yang negatif terhadap murid-murid berkeperluan khas yang terlibat dalam kelas inklusif.

Menurut Pajares (1992) pula, penyelidikan berkaitan kesediaan pendidik untuk melaksanakan pendidikan inklusif adalah sangat perlu termasuk kesediaan dan pengetahuan mereka. Hal ini kerana pengetahuan setiap guru berkaitan pendidikan inklusif adalah berbeza. Tambahan pula, pengetahuan guru berkaitan pendidikan inklusif serta penilaian diri terhadap kesediaan mereka untuk melaksanakan inklusif dapat mempengaruhi sikap mereka semasa melaksanakan inklusif. Justeru, Zagona et al. (2017) mendapati terdapat perbezaan yang ketara berkaitan pengetahuan mengenai pendidikan inklusif antara guru arus perdana dan guru pendidikan khas. Guru pendidikan khas dikatakan mempunyai lebih pengetahuan berkaitan pendidikan inklusif kerana mereka mempunyai asas berkaitan inklusif yang sememangnya telah dipelajari di universiti. Manakala, guru arus perdana pula masih kurang pengetahuan berkaitan pendidikan inklusif. Malah, guru pendidikan khas menyatakan mereka tidak berasa selesa untuk berkolaboratif dengan guru arus perdana kerana merasakan seolah-olah tiada persefahaman antara mereka berkaitan inklusif. Justeru, agak sukar untuk melaksanakan kolaboratif antara guru arus perdana dan guru pendidikan khas.

Justeru dapat dirumuskan bahawa hasil kajian lalu mendapati bahawa pengetahuan guru arus perdana terhadap pelaksanaan pendidikan inklusif adalah masih kurang. Malah, terdapat segelintir guru arus perdana dikatakan mempunyai sikap dan pandangan yang negatif terhadap murid berkeperluan khas yang terlibat dalam pendidikan inklusif. Perkara ini seharusnya tidak berlaku dan haruslah dibendung sekiranya ingin memastikan pendidikan inklusif dapat dilaksanakan dengan jayanya di sekolah. 


\section{Metod Kajian}

Kajian ini menggunakan pendekatan kualitatif dengan menggunakan reka bentuk kajian kes iaitu pelbagai kes dan pelbagai tempat. Menurut Mok (2010), pendekatan kualitatif menggunakan bahasa untuk menjelaskan fenomena pembelajaran yang mempunyai ciri khusus yang kompleks. Malah, pendekatan kualitatif dikatakan amat sesuai apabila sesuatu kajian melibatkan pemerhatian ke atas seseorang individu mahupun unit, satu kelas, sekolah, satu masyarakat, peristiwa dan budaya (Creswell 2013).

Dalam kajian ini, lima orang guru arus perdana sekolah rendah telah dipilih dan telah mendapatkan persetujuan daripada mereka terlebih dahulu untuk dijadikan sebagai peserta kajian. Guru-guru tersebut dipilih berdasarkan pengalaman mereka melaksanakan pendidikan inklusif. Hal ini telah memudahkan peserta kajian memperoleh data yang berguna untuk menjawab soalan kajian.

Seterusnya, instrumen yang digunakan dalam kajian ini adalah melalui pemerhatian dan temu bual. Bagi meneliti kemahiran guru aliran perdana dalam mengaplikasikan pengajaran dan pembelajaran inklusif dalam bilik darjah, pemerhatian merupakan salah satu sumber utama untuk mendapatkan data kajian. Hal ini kerana, pemerhatian dapat mengutip data tentang perkara yang sebenarnya berlaku dalam kelas (Van, 2007). Pengkaji juga telah memerhati persekitaran bilik darjah seperti cara guru menyampaikan bahan pengajaran, interaksi antara guru dan murid, dan aktiviti yang dilaksanakan. Protokol catatan pemerhatian kelas telah dibentuk dan disemak oleh dua orang pakar yang mempunyai pengalaman dalam bidang berkenaan sebelum kerja lapangan dijalankan. Daripada catatan lapangan kerja, satu refleksi tentang pemerhatian kelas tertentu juga akan direkod oleh pengkaji.

Seterusnya adalah temu bual. Kaedah temu bual dapat dibahagikan kepada tiga jenis iaitu temu bual berstruktur, temu bual separa berstruktur dan temu bual tidak berstruktur. Justeru, temu bual yang dipilih dalam kajian ini adalah temu bual separa berstruktur. Terdapat lima orang guru sekolah rendah telah dipilih untuk dijadikan sebagai peserta kajian untuk ditemu bual. Ketiga-tiga sememangnya mempunyai pengalaman dalam melaksanakan pendidikan inklusif di dalam bilik darjah. Melalui penggunaan pelbagai kaedah bagi mendapatkan data juga adalah untuk mengesahkan dapatan. Manakala, bukti pelaksanaan temu bual dan pemerhatian yang dijalankan adalah untuk meningkatkan kebolehpercayaan.

Penganalisisan data pula merupakan aktiviti untuk memperolehi maklumat yang berguna daripada data mentah. Menurut Marohaini (2001), bagi sebuah kajian kualitatif, proses pengutipan data dan penganalisisan data berjalan serentak dan seiring, bukannya secara langkah demi langkah. Proses analisis data temu bual dimulakan dengan mendengar semula rekod temu bual dan proses verbatim dilakukan untuk mendapatkan data mentah. Data yang ditranskripsikan akan dianalisis menggunakan program Nvivo serta berpandukan proses analisis yang disarankan oleh Gay, Mills dan Airasian (2006). Menurut Dayang, Abdul Hafidz dan Rio (2017), proses menganalisis data kualitatif melibatkan tujuh peringkat iaitu transkripsi, organisasi data, pelaziman, koding, tema, demonstrasi kebolehpercayaan serta kesahan dan laporan. 


\section{Dapatan Kajian}

Dapatan kajian ini merupakan data kajian kes bagi menjawab semua persoalan kajian. Kajian ini melibatkan data temu bual dengan guru-guru arus perdana yang melaksanakan pendidikan inklusif, selain itu pemerhatian pengajaran dan pembelajaran di dalam dan di luar bilik darjah juga dilaksanakan untuk menjawab setiap persoalan kajian. Hasil dapatan kajian ditunjukkan dalam Jadual 1.

Jadual 1: Tema Kajian

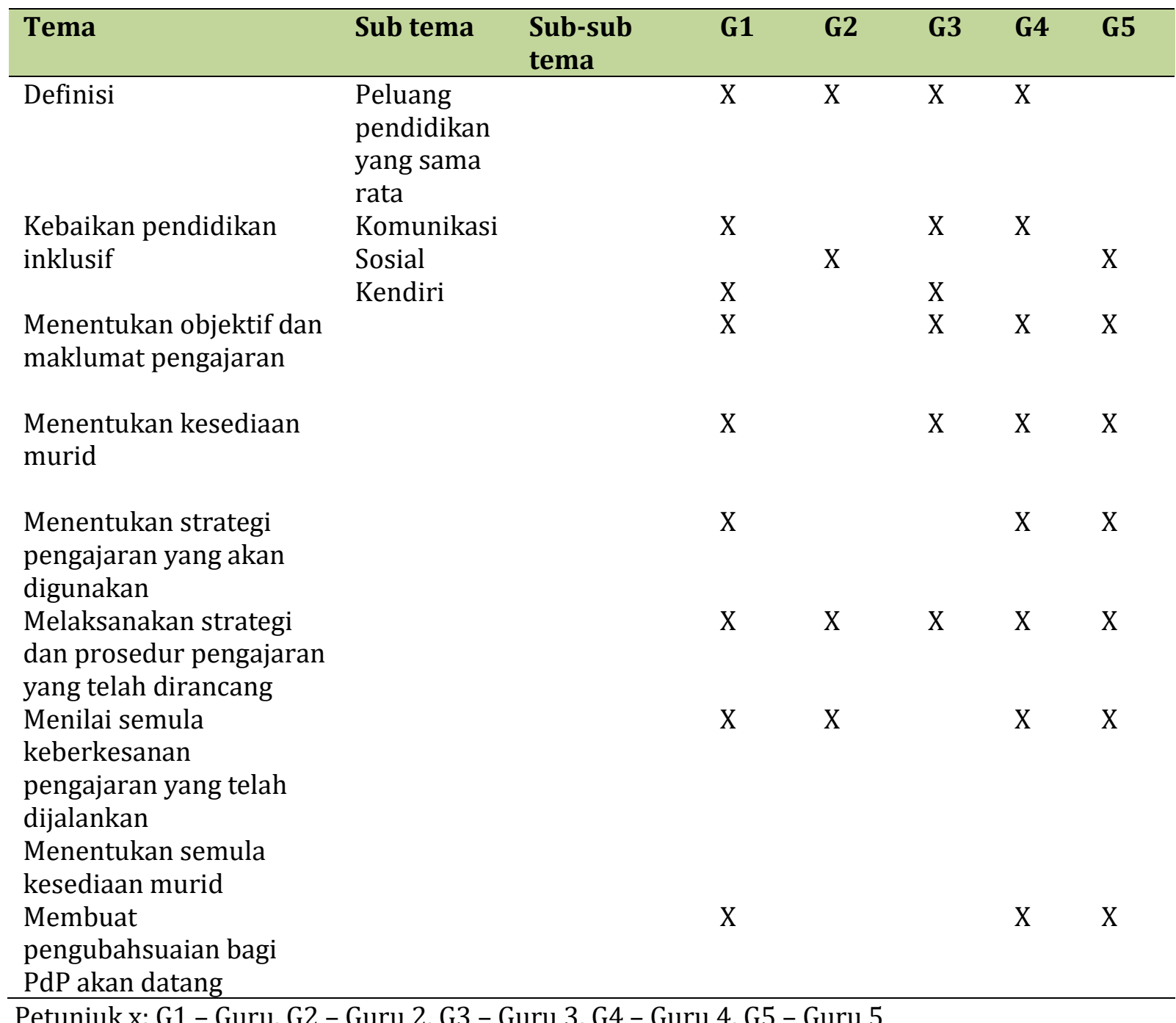

\subsection{Bagaimanakah pengetahuan pendidikan inklusif dalam kalangan guru arus perdana?}

Jadual 1 menunjukkan jadual tema yang terhasil. Persoalan pertama ialah bagaimanakah pengetahuan pendidikan inklusif dalam kalangan guru arus perdana? Terdapat dua tema yang terhasil iaitu definisi dan kebaikan pelaksanaan pendidikan inklusif. Kesemua guru menyatakan bahawa perkara yang mereka ketahui mengenai definisi pendidikan inklusif ialah peluang mendapat akses kepada pendidikan yang sama rata terhadap murid-murid tipikal dan murid-murid berkeperluan khas. Kesemua guru turut menyatakan bahawa pelaksanaan pendidikan inklusif memberi kebaikan kepada murid berkeperluan khas dan juga murid-murid tipikal. Bagi G1, G3 dan G4, beliau menyatakan perkembangan kemahiran komunikasi merupakan salah satu kebaikan pendidikan 
inklusif, manakala G2 dan G5 pula berkaitan sosial. Selain itu, G1 dan G3 juga ada menyatakan mengenai perkembangan kendiri murid-murid berkeperluan khas adalah lebih positif apabila diletakkan untuk belajar bersama-sama dengan murid-murid tipikal.

Menariknya dapatan kajian ini kerana bertentangan dengan kajian yang dijalankan oleh Aliaa (2013) yang menyatakan bahawa tidak ada seorang pun daripada 28 orang guru aliran perdana yang ditanya dapat memberi maksud pendidikan inklusif dengan tepat. Kajian yang dijalankan menggunakan kualitatif dan kuantitatif itu menggambarkan bahawa guru-guru di aliran perdana kebanyakannya kurang mempunyai pengetahuan mengenai pendidikan inklusif. Hal ini kerana, maksud pendidikan inklusif itu sendiri mereka tidak dapat menjawabnya dengan tepat.

\subsection{Bagaimanakah guru arus perdana menjalankan proses pengajaran sebelum melaksanakan pendidikan inklusif di dalam bilik darjah?}

Persoalan kedua ialah bagaimanakah guru arus perdana menjalankan proses pengajaran sebelum melaksanakan pendidikan inklusif di dalam bilik darjah? Terdapat empat tema yang terhasil iaitu menentukan objektif dan maklumat pengajaran, menentukan kesediaan murid, menentukan strategi pengajaran yang akan digunakan dan menilai semula. Hasil temu bual serta pemerhatian menunjukkan kelima-lima peserta kajian sememangnya membuat persediaan dengan menentukan objektif dan maklumat pengajaran, menentukan kesediaan murid, menentukan strategi pengajaran yang akan digunakan sebelum melaksanakan proses pengajaran pendidikan inklusif.

Beberapa kajian tekah dilaksanakan antaranya ialah Mustafa dan Siti Fatimah (2018) mendapati bahawa 11 orang responden (91.66\%) membuat perancangan PdP untuk semua murid di kelas inklusif. Manakala, hanya terdapat empat orang responden (33.3\%) yang membuat perancangan PdP khusus untuk MBK pembelajaran di kelas inklusif. Malah disokong dengan 10 orang responden $(83.3 \%)$ telah melaksanakan pengajaran secara umum di kelas inklusif dan kesemua responden $(100 \%)$ bersetuju bahawa MBK pembelajaran memberi respon yang baik terhadap strategi pengajaran khusus untuk mereka di kelas inklusif. Justeru dapat membuktikan bahawa guru arus perdana harus merancang PdP dengan mengambil kira kebolehan MBK pembelajaran.

\subsection{Bagaimanakah guru arus perdana menjalankan proses pengajaran semasa melaksanakan pendidikan inklusif di dalam bilik darjah?}

Persoalan ketiga ialah bagaimanakah guru arus perdana menjalankan proses pengajaran semasa melaksanakan pendidikan inklusif di dalam bilik darjah? Terdapat satu tema yang terhasil iaitu melaksanakan strategi dan prosedur pengajaran yang telah dirancang. Hasil temu bual serta pemerhatian menunjukkan kesemua peserta kajian menyatakan bahawa mereka melaksanakan strategi dan prosedur pengajaran yang telah dirancang semasa memulakan proses pengajaran. Berpusatkan guru dan bahan merupakan antara strategi yang sering digunakan oleh guru-guru arus perdana semasa melaksanakan PdP dalam kelas inklusif.

Oleh itu, sebagai guru yang melaksanakan pendidikan inklusif haruslah bijak dalam memilih strategi pengajaran dan pembelajaran yang sesuai supaya MBK pembelajaran tidak ketinggalan semasa berada di dalam kelas inklusif. Perkara ini turut disokong oleh Tin dan Wah (2018) yang menyatakan guru arus perdana perlu sentiasa berusaha untuk 
merangka strategi terbaik bagi membantu MBK pembelajaran mengikuti pendidikan arus perdana.

\subsection{Bagaimanakah guru arus perdana menjalankan proses pengajaran selepas melaksanakan pendidikan inklusif di dalam bilik darjah?}

Persoalan keempat ialah bagaimanakah guru arus perdana menjalankan proses pengajaran selepas melaksanakan pendidikan inklusif di dalam bilik darjah? Terdapat tiga tema yang terhasil iaitu menilai semula keberkesanan pengajaran yang telah dijalankan, menentukan semula kesediaan murid, dan membuat pengubahsuaian bagi PdP akan datang. Hasil temu bual serta pemerhatian menunjukkan terdapat guru inklusif yang menyatakan mereka melaksanakan penilaian semula keberkesanan pengajaran yang telah dijalankan, menentukan semula kesediaan murid, dan membuat pengubahsuaian bagi PdP akan datang selepas menjalankan proses pengajaran pendidikan inklusif di bilik darjah, malah ada juga guru yang tidak menyatakan bahawa mereka melakukannya. Perancangan PdP bagi peringkat selepas juga haruslah dititikberatkan. Hal ini kerana, proses pengajaran dan pembelajaran bukanlah hanya berkaitan apa dan bagaimana guru ingin sampaikan sesuatu pengajaran kepada murid, bahkan guru juga haruslah mengetahui bahawa cara, pendekatan atau strategi yang digunakan itu benar-benar berkesan atau tidak dalam proses pengajaran dan pembelajaran.

\section{Implikasi Kajian}

Hasil kajian ini menunjukkan pelbagai pihak perlu memainkan peranan penting bagi membantu merealisasikan kejayaan pelaksanaan pendidikan inklusif. Oleh itu, berdasarkan dapatan kajian ini disarankan beberapa implikasi amalan perlu dilakukan oleh pihak-pihak yang terlibat seperti Kementerian Pendidikan Malaysia (KPM), pentadbir sekolah, guru arus perdana dan guru pendamping. Salah satu implikasi kepada KPM dalam memastikan pendidikan inklusif berjaya dilaksanakan di sekolahsekolah di Malaysia ialah memberikan konsultansi, memantau pelaksanaan pendidikan inklusif, menyediakan latihan dan sokongan perkembangan profesional guru di semua sekolah yang melaksanakan PPI. Menurut Tin dan Wah (2018) KPM juga berperanan mengadakan program-program latihan dalam perkhidmatan yang bertujuan membantu guru-guru arus perdana menguasai pedagogi inklusif yang berkesan.

Implikasi kepada pentadbir sekolah pula haruslah memastikan guru membuat pengubahsuaian kurikulum dan pedagogi bagi membolehkan MBK mengikuti pengajaran dan pembelajaran arus perdana. Hal ini penting bagi memastikan MBK tidak merasa mereka di diskriminasikan oleh guru dan rakan-rakan dari arus perdana. Selain itu, menyediakan staf-staf sekolah dengan latihan pembangunan profesional berhubung aspek amalan pendidikan inklusif bagi memberi galakan, pengiktirafan serta motivasi kepada guru-guru untuk melibatkan diri dengan PPI (Tin \& Wah, 2018).

Selain itu, sebagai guru yang terlibat secara langsung dengan Program Pendidikan Inklusif, terdapat beberapa implikasi kepada guru arus perdana. Antaranya ialah guru arus perdana juga perlu sentiasa berinovatif dalam merancang pengajaran dan pembelajaran. Perkara ini turut disokong oleh Tin dan Wah (2018) yang menyatakan guru arus perdana lebih digalakkan untuk menggunakan pendekatan multisensori iaitu melibatkan lebih daripada satu deria murid bagi menarik minat murid dan memudahkan MBK untuk memahami topik pengajaran yang disampaikan oleh guru. 
Justeru, guru perlu menggunakan pelbagai bahan bantu mengajar yang kreatif dan inovatif bagi merangsang multisensori murid untuk membantu pembelajaran MBK itu sendiri.

Implikasi kepada guru pendamping pula ialah guru pendamping perlu memberikan khidmat sokongan kepada guru mata pelajaran. Walaupun kelas inklusif akan diajar oleh guru arus perdana, namun guru pendamping memainkan peranan yang sangat penting. Guru pendamping, guru kelas dan guru arus perdana bagi mata pelajaran kelas inklusif tersebut haruslah membina hubungan yang baik kerana memerlukan kerjasama setiap pihak dalam melaksanakan pendidikan inklusif di dalam bilik darjah (Siti Fatimah \& Mustafa, 2018). Khidmat sokongan yang akan diberikan kepada guru mata pelajaran adalah dengan berkongsi pengalaman dan teknik modifikasi tingkah laku MBK yang berkesan (Siti Fatimah \& Mustafa 2018). Selain itu, membantu guru mata pelajaran untuk merangka aktiviti pengajaran dan pembelajaran selain membantu menyediakan bahan bantu mengajar yang diperlukan bagi melancarkan pengajaran guru mata pelajaran dan mengoptimumkan pembelajaran MBK.

\section{Kesimpulan}

Kesimpulannya, kajian ini telah mengkaji pelaksanaan pendidikan inklusif dalam kalangan guru arus perdana. Keputusan kajian menggambarkan walaupun terdapat peserta kajian yang dilihat masih kurang pengetahuan mengenai perancangan PdP bagi PPI, namun kesemua peserta kajian boleh dikategorikan sebagai guru arus perdana yang mempunyai pengetahuan mengenai pendidikan inklusif dan mereka juga melaksanakan pedagogi inklusif di dalam kelas. Bagi penyelidikan pada masa hadapan, pengkaji telah mencadangkan beberapa kajian lanjutan bagi penyelidik selanjutnya dan salah satunya adalah membanding bezakan pengetahuan antara guru arus perdana dan guru pendidikan khas dalam melaksanakan pendidikan inklusif. Kajian ini juga turut memberi implikasi kepada beberapa pihak seperti Kementerian Pendidikan Malaysia (KPM), pentadbir sekolah, guru arus perdana dan guru pendidikan khas bagi membantu merealisasikan kejayaan pelaksanaan pendidikan inklusif.

\section{Penghargaan (Acknowledgement)}

Terima kasih kepada pensyarah yang telah membimbing sepanjang kajian ini dijalankan serta terima kasih juga kepada semua peserta kajian yang telah memberikan kerjasama dalam menjayakan kajian ini.

\section{Kewangan (Funding)}

Kajian dan penerbitan ini tidak menerima sebarang tajaan atau bantuan kewangan daripada mana-mana pihak.

\section{Konflik Kepentingan (Conflict of Interests)}

Penulis tidak mempunyai konflik kepentingan sepanjang kajian ini dijalankan. 


\section{Rujukan}

Aliaa Ismail. (2013). Sikap dan peranan guru dalam memperkasakan Pendidikan Khas. Tesis, Fakulti Pendidikan dan Pembangunan Manusia: Universiti Pendidikan Sultan Idris.

Caldwell, J. (2010). Leadership development of individuals with developmental disabilities in the self-advocacy movement. Journal of Intellectual Disability Research, 54(11), 1004-1014.

Creswell, J. W. (2013). Qualitative Inquiry And Research Design: Choosing Among Five Approaches ( $3^{\text {rd }}$ ed.). Sage.

Dayang Tiawa Awang Hamid, Abdul Hafidz Haji Omar \& Rio Sumarni Sariffudin. (2017). Aplikasi perisian nvivo dalam analisis data kualitatif. $3^{\text {rd }}$ International Qualitative Research Convention, hlm. 1-18.

Florian, L. (2019). On the necessary co-existence of special and inclusive education. International Journal of Inclusive Education, 1, 1-14.

Gay, L., Mills. G. \& Airasian, P. (2006). Educational Research: Competencies for Analysis And Application ( $8^{\text {th }}$ Ed.). New York: Prentice Hall.

Lewis, R. B. \& Doorlag, D. H. (2011). Teaching Students with Special Needs In General Education Classrooms ( $8^{\text {th }}$ Ed.). New Jersey: Pearson Education, Inc.

Marohaini Yusoff. (2001). Pengutipan Dan Pengumpulan Data Perlakuan Dan Proses Menulis Karangan Dalam Bilik Darjah. Penerbit Universiti Malaya.

Mohammad Azman Jongkulin, Roslee Talip \& Muhamad Suhaimi Taat. (2019). Pendidikan Inklusif: Efikasi kendiri guru prasekolah. Malaysia Journal of Social Sciences and Humanities (MJSSH),4(7), 87-95.

Mok, S. S. (2010). Penyelidikan Dalam Pendidikan: Perancangan Dan Pelaksanaan Penyelidikan Tindakan. Penerbitan Multimedia Sdn. Bhd.

Mustafa Che Omar \& Siti Fatimah Salleh. (2018). Keperluan terhadap guru resos bagi Program Pendidikan Inklusif di sebuah sekolah menengah: Satu kajian kes. Seminar Kebangsaan Majlis Dekan Pendidikan Universiti Awam 2018, hlm. 14311447.

Norfishah Mat Rabi, Nor Hasnida Che Md Ghazali, Nor Aizal Akmal Rohaizad \& Mohd Yusof Zulkefli. (2018). Readiness of pre-service teacher to teach student with special needs through inclusive education course. International Journal of Academic Research in Progressive Education \& Development, 7(4), 200-210.

Norliah Mohd. Amin \& Mohd Hanafi Mohd Yasin. (2016). Pelaksanaan Program Pendidikan Inklusif murid berkeperluan khas dalam Pelan Pembangunan

Pendidikan Malaysia 2013-2015. International Conference on Special Education In Southeast Asia Region $6^{\text {th }}$ Series 2016, hlm. 29-35.

Pajares, M. F. (1992). Teachers' Belief and Educational Research: Cleaning Up a Messy Construct. Review of Educational Research, 62(3), 307-332.

Saloviita, T. (2020). Attitudes of teachers towards inclusive education in Finland. Journal of Educational Research, 64(2), 270-282.

Siti Fatimah Salleh \& Mustafa Che Omar. (2018). Masalah pengajaran guru dalam pendidikan inklusif di sekolah. Asian People Journal, 1(2), 243-263.

Tin, A. C., \& Wah, L. L. (2018). Pendidikan Inklusif. Petaling Jaya: Sasbadi Sdn. Bhd.

UNESCO. (1994). The Salamanca Statement and Framework for Action on Special Needs Education. Paris: UNESCO.

Van, R. E. (2007). An Illuminative Evaluation of The Workplace Learning Component Of UNISA's Diploma In Animal Health. School of Education: University of the Witwatersrand. 
Zagona, A. L., Kurth, J. A., \& MacFarland, S. Z. C. (2017). Teachers' views of their preparation for inclusive education and collaboration. Teacher Education and Special Education, 40, 163-178. 